\title{
Trabzon Kent Merkezinin Göstergebilim Yaklaşımı İle Okunması
}

\author{
Funda KURAK AÇICl${ }^{1 *}$, Elif SÖNMEZ ${ }^{2}$
}

Öz

Dilimizde, dilbilim sözcüğünden üretilmiş olan göstergebilim göstergeleri inceleyen bilim dalı olarak; bilimin her alanında karşımıza çıkmaktadır. Göstergebilimde seçilen bir dil ya da araç yardımıyla iletişim sağlanabilmektedir. Göstergebilimin kendine özgü, sınırları belli, tanımı yapılmış bir alanı yoktur. Her şey için göstergebilimden bahsedilebilir. Yaşamın her alanında, çevremizde olup biten her şey de göstergelerden yararlanarak iletişim kurulabilmektedir. Yapılı çevreyi oluşturan kent, içinde barındırdığı doğal yapay her türlü biçim, nesne ve olgu ile iletişim halindedir. Bir kenti, anlamak ve anlamlandırmak için iletişim aracı olan göstergelerden yararlanılabilmektedir. Bu anlamda tarihi bir kent olan Trabzon kenti, birçok uygarlığa ev sahipliği yapmış olması ve Karadeniz'in başkenti olarak değerlendirilmesi ile çalışma alanı olarak belirlenmiştir. Bu çalışmada, kenti okumak için göstergebilimden yararlanılmaktadır. Bir iletişim biçimi olan göstergebilim, kentin insana kattığı anlamlarla ifade edilmektedir. Çalışmanın gerçekleşmesi için gerekli araçlardan olan literatür taraması, alan araştırması, gözlem ve fotoğraflama teknikleri yöntem tercih edilmiştir.

Anahtar Kelimeler: Göstergebilim, Kent, Anlambilim, Trabzon

\section{Analysis of The City Center of Trabzon Through Semiotics}

\begin{abstract}
Semiotics addresses signs in every field of science. In semiotics, a language or means makes communication possible. Semiotics, however, has no distinctive and defined area. We can talk about semiotics for almost anything. We can use signs to communicate in all areas of life and for everything that happens around us. The cities that make up the built environment are in constant communication through their natural or artificial forms, and objects and phenomena. Signs, which are a means of communication, can be used to understand and make sense of cities. Trabzon is a historic city that has hosted many civilizations and is considered the capital of the Black Sea. It was, therefore, the area of interest of this study. The aim of this study was to use semiotics to analyse the city centre of Trabzon. The meanings that a city attaches to people are referred to as semiotics. Data were collected using literature review, field research, observation and photography techniques.
\end{abstract}

Keywords: Semiotics, City, City Center, Semantics, Trabzon

\footnotetext{
${ }^{1}$ Karadeniz Teknik Üniversitesi, Mimarlık Fakültesi, İç Mimarlık Bölümü

2 Altınbaş Üniversitesi, Güzel Sanatlar Fakültesi, İç Mimarlık ve Çevre Tasarımı Bölümü

* Illgili yazar/Corresponding author: fundakurak@ktu.edu.tr

Gönderim Tarihi / Received Date: 20.02 .2020

Kabul Tarihi / Accepted Date: 08.06.2020
} 


\section{GíRiş}

Kentler, insanların sosyal, kültürel, ekonomik, vb. her türlü gereksinimlerini karşılayabildikleri ve huzurlu bir şekilde barınmalarını sağlayan yerleşimlerdir. Kent, içinde bulunan halk ve çevresi ile şekillenen, yaşayanların oluşturduğu bir bütünü temsil eder. Kent içinde yaşayan insanların; yaşayış tarzları, kültürleri ve davranışları sonucunda kent kurgusu biçimlenerek kentin genel yapısı oluşur.

Kentlerin oluşması ve gelişmesinde coğrafi özellikleri son derece etkilidir. Trabzon kenti, özellikle de kent merkezi, Değirmendere vadisi boyunca, vadinin denize doğru indiği güzergâhın batısında, Boztepe'nin aşağıya doğru inen sırtında, kotlar halinde denize inen düzlükler üstüne yerleşir. Kıyı bölgesinde, yapılaşmanın çok seyrek olduğu, vadi boyunca içlere doğru kentin yayıldığı görülmektedir. Yerleşim alanları daha çok kıyı şeridinde yoğunlaşmıştır. (Arü, 1998, s. 49)

Kent, kent meydanı ve meydana ulaşan paralel üç ayrı sokak şeklinde konumlanmıştır. Kent merkezi olan meydan ve çevresi kentin sahil şeridinden daha üst ölçeğinde yer almaktadır. Kent meydanı ve çevresi tarihi yapıları ile farklı bir dile sahiptir. Meydana ulaşan sokaklar üzerinde de yine eski yapılar ile tarihi bir dil hakimdir.

İçinde yaşayan insanlar tarafından şekillenen kent, geçmişten günümüze birçok kültürü beraberinde getirmektedir. Trabzon kenti, Miletli'lerden Osmanlı'lara kadar çok farklı medeniyetleri içinde barındıran bir kültür mozaiği görünümündedir. Kent meydanı da bunun bir göstergesi olarak bize yansımaktadır.

Dilimizde, dilbilim sözcüğünden üretilmiş olan göstergebilim göstergeleri inceleyen bilim dalıdır. Göstergebilimin ifade ettiği şeylere bakıldığında ondan bir iletişim modeli olarak bahsedilebilir. Bilginin aktarılması, göstergelerin yorumlanması için bildirişime yani iletişime intiyaç vardır. Göstergebilimde seçilen bir dil ya da araç yardımıyla iletişim sağlanabilmektedir. Göstergebilimin kendine özgü, sınırları belli, tanımı yapılmış bir alanı yoktur. Her şey için göstergebilimden bahsedilebilir. Yaşamın her alanında, çevremizde olup biten her şey de göstergelerden yararlanarak iletişim kurabilmekteyiz. Yapılı çevreyi oluşturan kent, içinde barındırdığı doğal yapay her türlü biçim, nesne ve olgu ile iletişim halindedir. Bir kenti, anlamak ve anlamlandırmak için iletişim aracı olan göstergelerden yararlanılabilmektedir.

Trabzon kenti, tüm doğu Karadeniz bölgesine hizmet veren merkez kent konumunda bulunmaktadır. Kentte yaşayanların yanı sıra, çevre illerden gelenlerin de bir toplanma alanı olan kent meydanı; oteli, sineması hatta bir dönemler varlığını sürdüren opera yapısı ve diğer kamusal yapılarıyla önemli bir merkez görevini üstlenmiştir. Çevik'in dediği gibi, "Yerleşim sisteminde mekansal anlamda işlevsel bir düğüm olarak nitelendirilecek kent, sadece kendi nüfusuna değil, art bölgesindeki nüfusa da hizmet veren ve karşılığında hizmet alan bir yerleşim birimidir" (Çevik, 2005, s. 64). Trabzon da olduğu gibi, kent; sadece kendi sınırları içinde dışarıdan kendini soyutlayarak yaşamaz, sürekli bir etkileşim içindedir.

Bu çalışmada, kenti okumak için göstergebilimden yararlanılacaktır. Bir iletişim biçimi olan göstergebilim, kentin bize kattığı anlamlarla ifade edilecektir. Bu anlamda tarihi bir kent olan Trabzon kenti, birçok uygarlığa ev sahipliği yapmış olması ve Karadeniz'in başkenti olarak değerlendirilmesi ile çalışma alanı olarak seçilmiştir. Özellikle kentin buluşma noktası niteliğindeki kent meydanı ve çevresinde bulunan, yapıları ile göstergebilim açısından iletişim aracı olarak okunmaktadır (Şekil 1). 


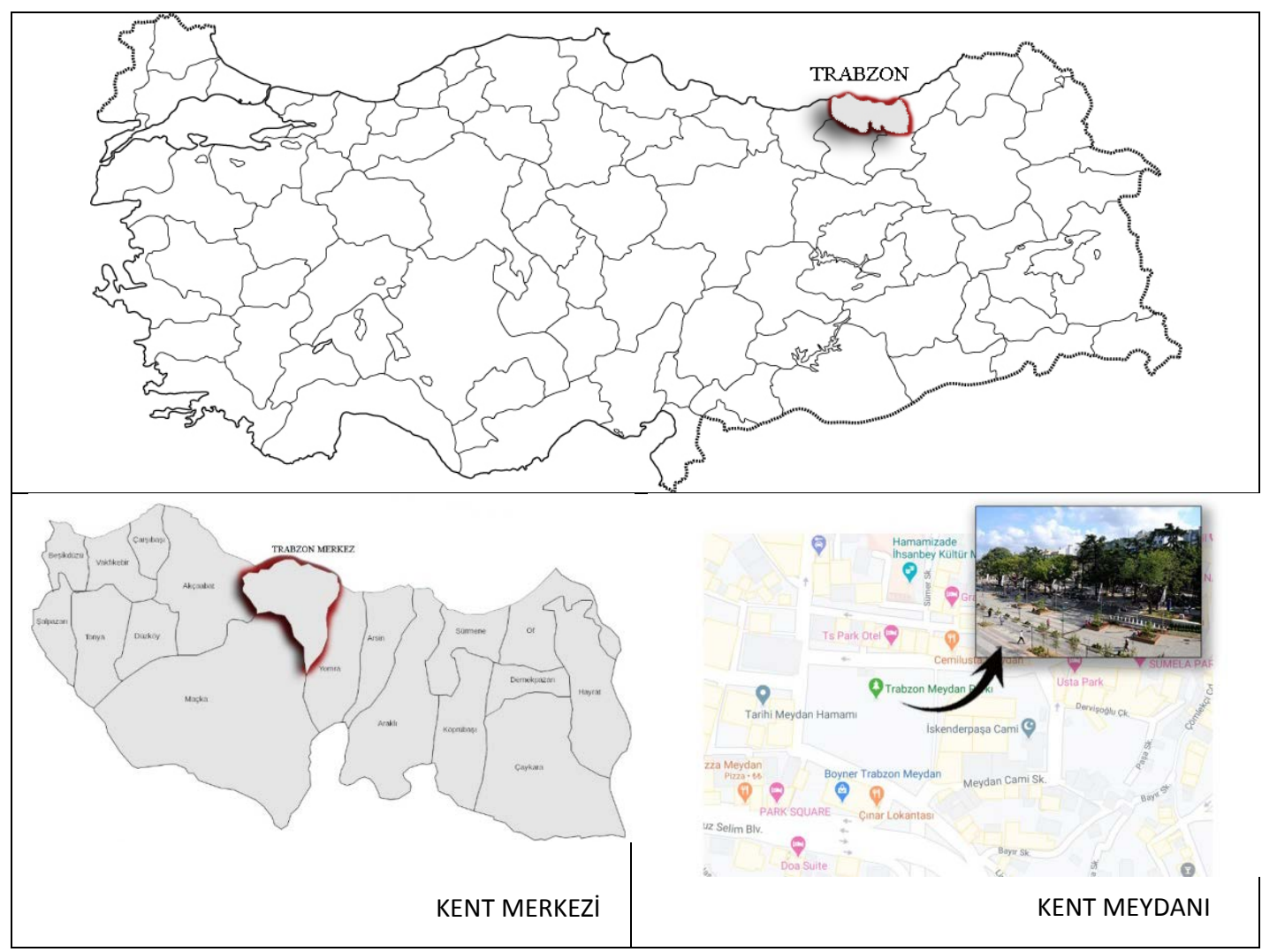

Şekil 1. Trabzon Kentinin Konumu ve Kent Meydanının Yeri

$\mathrm{Bu}$ araştırma yapılı çevreye ilişkin göstergelerin kentin nasıl ifade edildiği ve iletişim kurduğu çevre ile hangi araçlarla kente dair söylemlerde bulunduğunu ortaya koymak amaçlanmıştır. Çalışma kapsamında göstergebilimin kent ölçeğinde ele alınması istenmiştir. Bu anlamda geçmiş dönemlerden beri birçok medeniyete ev sahipliği yapmış olan, tarihi değerleri ile bellekte izler barındıran Trabzon kenti ele alınmaktadır. Trabzon kenti içinde de, kentin merkezini oluşturan; kentin kimliğini ortaya koyan; kent meydanı değerlendirme kapsamına alınmıştır.

\section{YÖNTEM}

Araştırma değerlendirme ölçeğinde tüm bölgenin ele alınmasının hem zaman, hem de işgücü anlamında zorluğu nedeniyle ve genel olarak da bölgedeki yapıların benzer özellik taşıdığı öngörüldüğünden kenti ifade eden kenti en iyi şekilde anlatabileceği düşünülen kent merkezi çalışma genelinde sınırlandırılmıştır. Bu çalışmada, Trabzon kent merkezi ile ilgili bilgiler toplanmış, yerinde gözlem yapılmış, kent ile ilgili fotoğraf ve belgelerden yararlanılmıştır. Kenti oluşturan öğeler, kentin anlatan kentin çevresi ile iletişimini sağlayan göstergeler göstergebilim yardımı ile değerlendirilmiştir.

\section{GÖSTERGEBILIMM KURAMI}

Göstergebilim, en öz ifade ile; insanın kendi için ve dünyanın insani boyutta taşıdığı anlamları/ifadeleri araştıran bir bilim dalıdır.

Göstergebilim, 1950'lerden sonra dilbilim ve edebiyat araştırmacılarının tekelinden çıkarak tüm yaşam alanlarında etkisini göstermeye başladı. Özellikle Umberto Eco ve Roland Barthes göstergebilime farklı gözle bakılabileceğini gösterdi. Mimari, şehir 
planlaması, endüstri ürünleri tasarımı, moda, mitoloji, antropoloji, sinema ... gibi bir çok alanda göstergebilimin varlığı kabul görmüş oldu (Kurak Açıcı, 2013, s. 8).

Ch. S. Pierce mantıksal kökenli bir göstergebilimin temelini attığını düşünür ve tasarladığı bu genel göstergebilim kuramını da mantıktan yararlanarak üç bölüme ayırır:

1. Sözdizim (sentaks): göstergelerin aralarındaki ilişkileri araştırır; göstergelerin, birleşik göstergeler (bildiriler) oluşturmak için nasıl bir araya geldiklerini inceler;

2. Anlambilim (semantik): göstergelerin belirttikleri anlamları, yani gösterge ile gösterilen arasındaki ilişkiyi inceler;

3. Edimbilim (pragmatik): göstergeler ile bunları kullananlar arasındaki ilişkiyi inceler (Rifat, 2009, s. 34).

Rifat, göstergebilimden iki şekilde bahseder, bunlardan ilki Bildirişim (Semiyoloji) ikincisi de Anlamlama (Semiyotik) Göstergebilimidir. Göstergeleri bildirişim açısından inceleyen semiyoloji, benimsediği gerçekçi yaklaşım ile, gerçekte var olan, dokunulabilir, hissedilebilir, somut, fiziksel nesneleri anlatıyormuş gibi, 'dil'e ve 'dilyetisi'ne yüzeysel boyutta başvurur. Bu biçim dilbilim yöntemlerinden yararlandığı için Bildirişim Göstergebilimi olarak adlandırılır. Dil yetisini gözlemlenecek tek katmanlı bir nesne olarak değil, oluşturulmuş, inşa edilmiş, anlamsal katmanlardan kurulu bir bütün olarak gören semiyotik, oluşum sürecini yeniden kavramaya ve yeniden anlamlandırmaya çalışır. Yeniden kavrama ve adlandırma aşamasında gözlemlenebilen dil, betimlemekle yetinmez, genel bir dilyetisi kuramını yaratmayı hedefler ve bilim kuramı biçimine getirmeyi konu edinir. Buradaki yaklaşım, Anlama Göstergebilimi olarak adlandırılır (Rifat, 2009).

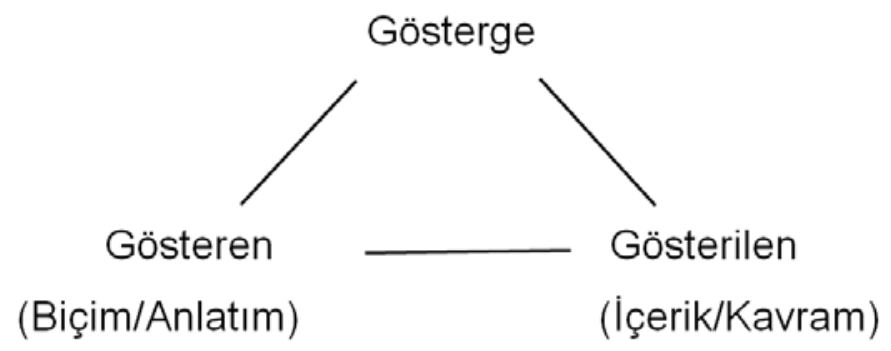

Şekil 2. Pierce'in Göstergesi (Erkman, 1987)

İnceleme alanından da anlaşılacağı üzere göstergebilim birçok kaynaktan ve alandan beslenmektedir (Şekil 2). Tarihsel olarak geçirdiği evrelerle ve günümüz teknolojileri ile birleşerek birçok farklı disiplinle de ilişki kurabilmektedir. Bu anlamda özellikle de kentsel ölçekte ele alınması gereken mimarlık alanı da göstergebilimin inceleme alanlarından biri olarak yerini almaktadır.

Roman Jakobson'un iletişim şeması ile ifade edilmek istenen, konuşan öznenin alıcısına anlamlı bir ileti göndermesi için bir bağlam (gerçek dünya), bir kod (yazı, nota, rakam, vb.) ve bir kanal (kitap, dergi, televizyon, vb.) kullanmak zorunda olduğudur. (Şekil 3). (Güneş, 2013). 


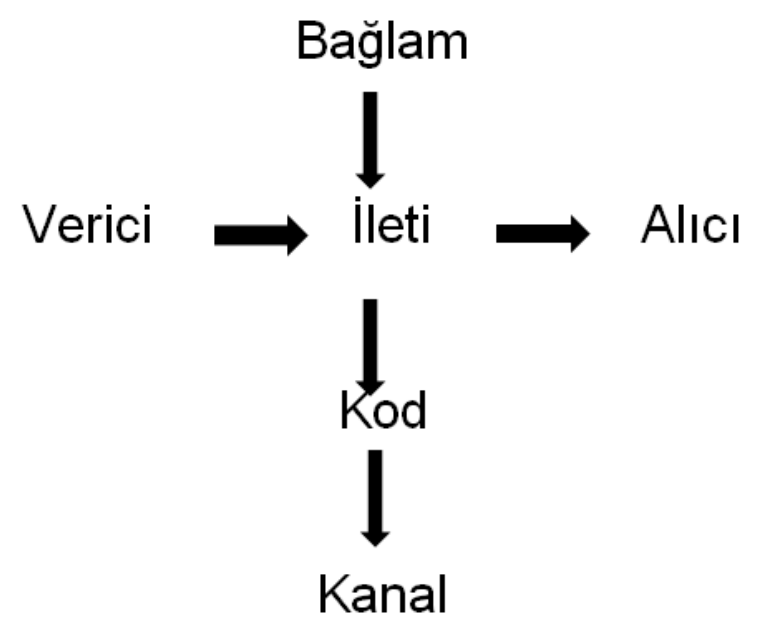

Şekil 3. İletişim Şeması

Kenti oluşturan yapılar bütünü göstergebilim açısından ele alındığında, göstergelerin anlamları gözlemlenebilir, somut ve fiziksel nesnelerle ifade bulabilmektedir. Kenti okumak için, göstergebilimin anlamlama (semiyotik/semantik) göstergebilim referans alınması bu çalışma için uygun görülmüştür.

\section{4. ÇALIŞMA ALANI: TRABZON KENTI}

Geçmişten günümüze, medeniyetlerin gelişmesiyle, mimari ve mekan kavramları, zamanın da değişimi ile kullanıcı gereksinimlerine bağlı olarak farklılaşmıştır. Farklı kültürlerin izlerini taşıyan mimari öğelerin bir araya gelmesiyle kentler oluşmuştur. Kentleri oluşturan kentsel mekanlar, içinde barınan halkın intiyaçları ile şekillenmiştir. Kentsel mekanlar, kent halkının bir araya gelmesini sağlayan ve kent yasamı içerisinde önemli görevler üstlenen mekanlardır. Kentin oluşumunda etkili olan sokaklar ve meydanlar, kentin açık mekanları olarak kenti tanımlayan alanladır. Meydanlar, kentlinin bir araya geldiği kentsel iletişimin ve birlikteliğin sağlandığı alanlardır. Sokaklar ise, meydanların oluşumunu sağlarken ve çevresinin de şekillenmesi ile oluşur.

Bu kapsamda, çalışma alanı olarak tarihi bir kent olan Trabzon kenti, kent meydanı ve meydanın oluşumunda etkili olan meydanı çevreleyen yapıları ile ele alınmaktadır (Şekil 1). Tarih boyunca pek çok millete ev sahipliği yapmış olan Trabzon kenti, tarihi ve kültürel zenginliği, doğal güzellikleri ve stratejik konumu ile önemli bir yere sahiptir. Köklü tarihi geçmişi, çok katmanlı kültürel yapısı yanında, tarihi İpek Yolu üzerinde bulunması ve Bizans, Komnenos ve Osmanlı Devleti hakimiyeti dönemlerinden itibaren limanı günümüze kadar işlevini sürdürmüştür.
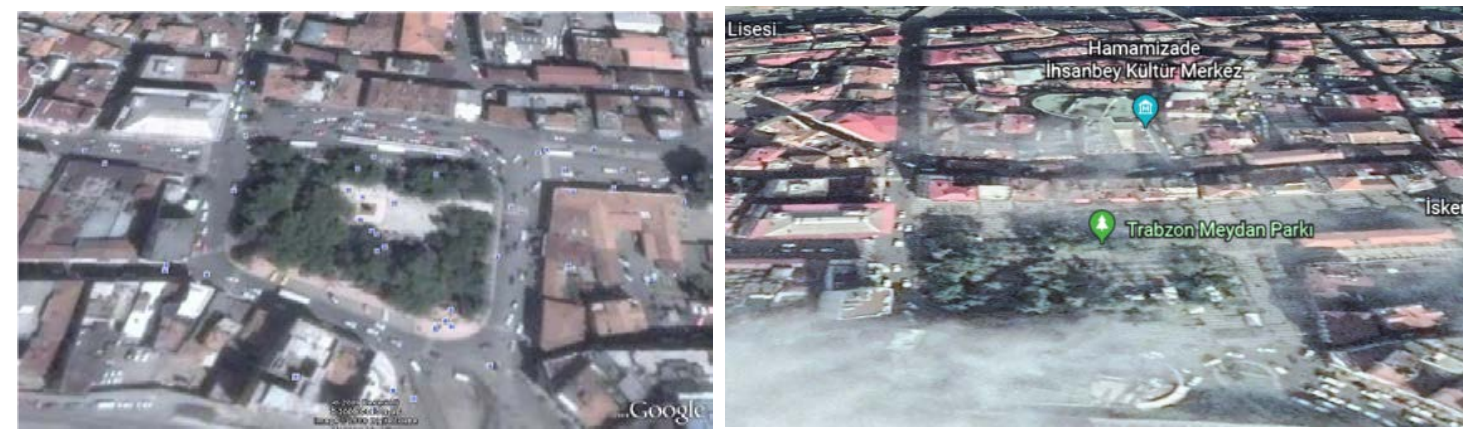

Şekil 4. Trabzon Kent Meydanı 2009-2017 (Url-1, 2017). 
Trabzon kentinin en eski tunç devrine kadar uzanmakta olduğu birçok tarihi kaynakta belirtilmekte ve son arkeolojik kazılarla da desteklenmektedir. Kentin ilk yerleşiminin M.Ö. 2000 yıllarına kadar gitmekte olduğu ve Orta Asyalı Türk kavimler tarafından kurulduğu düşünülmektedir (Öksüz, 2004). Çok eski tarihe sahip bir kent olan Trabzon'un, geçmişten günümüze birçok medeniyete ev sahipliği yapması ve coğrafik konumu nedeniyle her dönem önemli bir yerleşim alanı olmasını açıklamaktadır.

Tarihte her dönem ticari açıdan önemli olan Trabzon, Boğazlar ve Ege yoluyla Akdeniz'e ve Avrupa'ya bağlanmasının yanı sıra Karadeniz üzerinden de Rusya'ya ve Avrupa'ya kadar giden yolların merkezinde olmasıyla da özel bir konumda yer almaktadır (Turan, 1990).

Kentin merkezini oluşturan kent meydanı, eski adıyla gavur meydanı, daha çok yabancı halkın yaşadığı ve ticaret-alışveriş işlevinin sürdürüldüğü alan olarak kente hizmet vermekteydi. Günümüzde de kentin merkezinde ticaretin yoğun şekilde devam ettiği bir alan olan meydan, 2013 yılında yeniden projelendirilmiş, çevresi ile yeniden düzenlenerek kentli için daha sosyal bir alana çevrilmiştir. Kent mekanının göstergebilimsel analizi, bir yandan yöntem olarak diğer ölçeklerdeki analizlerin yapısalcı yöntemini kullanırken, diğer taraftan konuya toplumbilimsel ve tarihsel yorumlarla da buluşturmak olanağı vermektedir. Kentsel mekan için göstergebilimsel yorumlama, kentin içinde yer alan onun öğelerini temsil eden bağlantılardan oluşan bir dizge-dizim ile ele alınmaktadır. Bu yaklaşımla, sahip olduğu mekan düzeni içindeki tüm anlamsal farklılaşmaları nesnel olarak ortaya çıkaran kentin, sonuçta kökeni ve gelişimini inceleyen dili ortaya koyulmaktadır.

\subsection{Kenti Okumak: Göstergebilimsel Yaklaşımlar}

Kent, onu tanımlayan kentsel mimari ile algılanmaktadır. Kentin bütününü kentin insanları ve tasarladıkları binalar oluşturmaktadır (Rossi, 2006). Kenti tamamlayanın insan olduğu düşünüldüğünde kenti anlamak daha anlamlı hale gelmektedir.

Kentler belirli merkezler üzerine kurulmaktadır. Kentin odak noktası sayılabilecek merkezler etrafında gelişen ve büyüyen kent, bu merkezlerle anılmaktadır. "Kentlerin, sosyo-kültürel açıdan önemli bir merkez niteliği kazanmasında, dini, siyasi ve ticari işlevlerin, tarihsel dönemlere göre değişen veya biriken ağırlıklarının önemli bir rolü vardır" (Ter, Özbek, 2005, s. 529).

Kent merkezi denildiğinde akla meydanlar gelmektedir. Kentin odak noktasında bulunan meydanlar kent için önemli bir anıtsal değer taşımaktadır. "Bir kentin merkezi sayılan meydanlar, diğer kentsel mekan elemanları olan cadde ve sokak ağlarına göre, sosyal yaşamın daha fazla yansıtıldığı alanlar olma özelliğini taşıyor. Kullanıcının duygusal deneyim yaşadığı fiziksel ve psikolojik fonksiyonu olan bu alanlar, kullanıcıyı cadde ve sokaklardaki akıştan uzaklaştırıp koruma sağlayarak bir nevi özgürlük olanağı yaratıyor ki dünyadaki pek çok meydan Özgürlük Meydanı olarak adlandırılıyor. Sosyal yaşantının geçtiği mekanlar tarih boyunca Eski Yunan şehrinde agora, Roma döneminde forum olarak karşımıza çıkıyor" (Öztaşkın, 2008). Kentin merkezi olarak kabul edilen meydanlar kentin göstergeleridir. Kentin genel yapısı hakkında bilgi verir, taşıdığı izlerle kent ile iletişim kurulmasına olanak sağlar.

Doğu Karadeniz Bölgesinin tarihe tanıklık eden yanı ile önemli şehirlerinden biri olan Trabzon, konum olarak tarihi ipek yolu üzerinde olmasından dolayı ticari, siyasi, askeri ve sosyo-kültürel açıdan önemini hiç yitirmemiştir. Eski dönemlerden beri farklı medeniyetlere ev sahipliği yapması nedeni ile özelliklede Roma, Bizans ve Osmanlı 
dönemlerine ait pek çok mimari eser halen varlığını sürdürmektedir (Öksüz, 2004, s. 51). Trabzon Kent Merkezdeki alanın meydan niteliğinin belirlenmesinde, Rum Pontus ve Osmanlı dönemine ait yapısal özelliklerin, kültürün, geleneklerin, ticaret ağının ve sosyal yaşamın getirdiği şeylerin etkileri olmuştur. Bu nedenle meydanı oluşturan yapı grupları, kentin farklı dönemlerinden izler taşıyarak kentin tarihinin birer göstergeleri konumundadır.

Karadeniz'in başkenti olarak nitelendirilen Trabzon kenti, tarihsel süreç içinde, idari ve ekonomiye yön vermesi açılarından olduğu kadar, sosyal ve kültürel yönüyle de merkez bir kent olma özelliğini sürdürmüştür. Kentin tarihsel oluşumu ile kentlilerin kültürel kimliği birbiriyle ilişkili olarak süregelmiştir. Farklı medeniyetlerin barındığı kent, kentlilerin yaşama kültürü ve medeniyetlerin ortak kalıtları ile sentezlenmiştir. Bu kültürel birikimlerin sonucunda kente anlam veren mekanlar oluşmuştur. Bu mekanlardan en önemlisi sayılabilecek kent merkezi kent meydanı ile kimlikleşmektedir. Trabzon'un en tanınmış, merkezi sayılabilecek noktasında yer alan meydan; Meydan-ı Şarki, Gavur Meydanı, Hürriyet Meydanı ve Belediye Meydanı isimleriyle anılarak günümüze kadar gelmiştir.

1 Belediye Binası, 2 Gazeteciler Cemiyeti, 3 Park Oteli,

4 Kunduoğlu Konağı, 5 Eski Selamet Oteli, 6 İskenderpaşa Camii

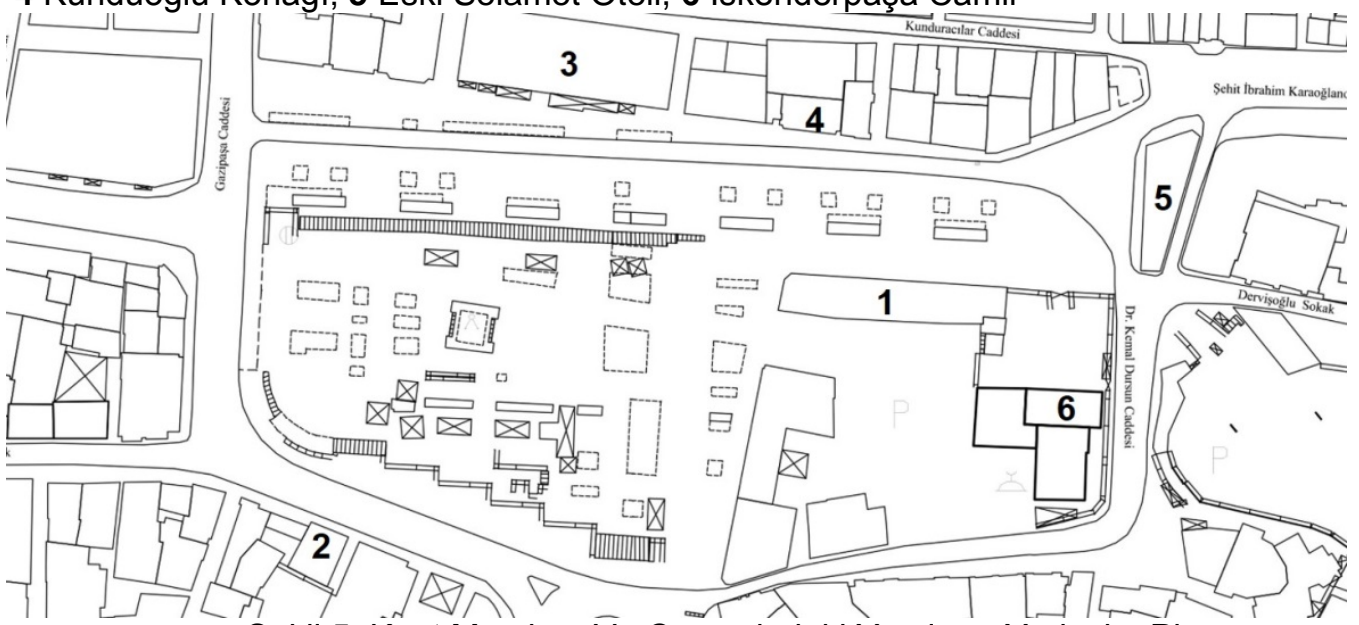

Şekil 5. Kent Meydanı Ve Çevresindeki Yapıların Yerleşim Planı

Meydanı çevreleyen sokak, belli bir doğrultuda yönlenmeyi sağlarken, meydan hareketliliğe zorlamayan bir dinlenme alanı olarak yerini korumaktadır. Kentin odak noktasında bulunması ile kent için bir nirengi noktası olarak baskın yapıda meydan yerini almaktadır. Sokakların yönlendirmesiyle kentliler için ulaşılacak nokta olarak ön plana çıkmaktadır. Kentin genel yapısında da meydana doğru bir yönlendirme mevcuttur (Şekil 5). Kentin bir noktasından başka bir noktasına ulaşılmak istendiğinde, mutlaka meydana önce erişim sağlanması gereklidir. Kentin tüm mahalle ve semtlerine ulaşan trafik ağının merkezi de meydanda bulunmaktadır. Bu açıdan değerlendirildiğinde de kentin anlamak kent meydanını tanımlamakla mümkündür.

Trabzon kenti, tarihi geçmişin yoğun olduğu bir yapı taşımakta olduğundan kentin tarihinden gelen anlamsal bütünlük ile kentin modern yaşamını temsil eden yaşamsal gereklilikler arasında görülür bir çatışma bulunmaktadır. Kentin kurulduğu merkez yıllar boyunca yer değiştirmemiş olduğu gibi kullanılmaya devam etmiştir. Bu durum zaman zaman büyüyen kent için yetersiz olmuş ve çözüm yolları aranmıştır. Kent meydanı, eski tarihlerden beri tamamen yollarla çevrili olarak konumlandırılmıştı. Kent için yeterli görülmeyen, yaya trafiğine açılması öngörülen meydan, 2010 yılında yeni bir proje ile 
yeni kimliğine kavuşturulmuştur. Bu durumda, tarihin izlerini taşıyan meydanın, yeri, yapısı ve etrafı değiştirilmemiş, yalnız etrafını çeviren yollardan, doğu ve kuzey tarafında bulunanlar kapatılarak yaya trafiğine arttırılmış ve meydanın alanı genişletilmiştir. Bir anlamda tarihi yapılarla çevrili meydanın modern bir yaşam alanına dönüştüğü söylenebilir. Geçmiş ile geleceği birleştiren bir arayüz konumunda olan meydan parkı kentin en önemli göstergesi olarak varlığını yeni yüzü ile de korumaktadır.

Meydanın kent içinde kimlik ve anlam kazanmasında etkili olan sadece merkezde olması değildir. Kent meydanı etrafındaki yapıları ile de kimlik kazanmaktadır. Yapıların tarihi ve mimari değeri, kamusallığı kadar kentliler için ne kadar kullanıldıkları da önem kazanmaktadır. Özelliklede bitişik nizamda bir araya gelişleri, uyum içindeki cephe kurguları ve meydanı sınırlayıcı etkileriyle kent için birer gösterge olma özelliğindedirler. Kentin kimliğini oluşturan kentliler, kültür birikimleri ve geçmişten günümüze kenti anlatan mimari eserlerdir. Bu nedenle kenti siluetinde var olan yapılar, yeni yapılar ile birlikte ne derece uyumlu olursa kentin hafızalarda bıraktığı anlam da o derece başarılı olmaktadır. Burada önemli olan yapıların karakteristik özelliklerinin kentin belleğindeki yeridir.

Kentin sosyal, idari, ticari ve kültürel intiyaçlarına göre meydana getirilmiş ve alanın belirleyici unsurları olan yapılar bu özellikleri ile tarihin en önemli tanıklarıdır. Geçmişten günümüze, her dönemin bir önceki dönemden devraldığı kentte meydana gelen değişimleri tespit etmekte en önemli kaynaklarıdır. Meydan çevresinde, kentin ve buna bağlı olarak alanın yüklediği misyona göre zaman içinde birçok yapı inşa edilmiştir (Yalçınkaya, Demirkaya, 2011). Geçmişten günümüze pek çok medeniyete ev sahipliği yapmış bir kent olan Trabzon'un, geçirdiği tarihsel süreçte barındırdığı medeniyetlerin izlerini büyük ölçüde koruduğu görülmektedir. Antik dönemden günümüze geçirdiği siyasi, ekonomik ve sosyal değişimlerin etkisiyle birçok yapının da yok olduğu bilinmektedir (Aras, İslamoğlu, 2018).
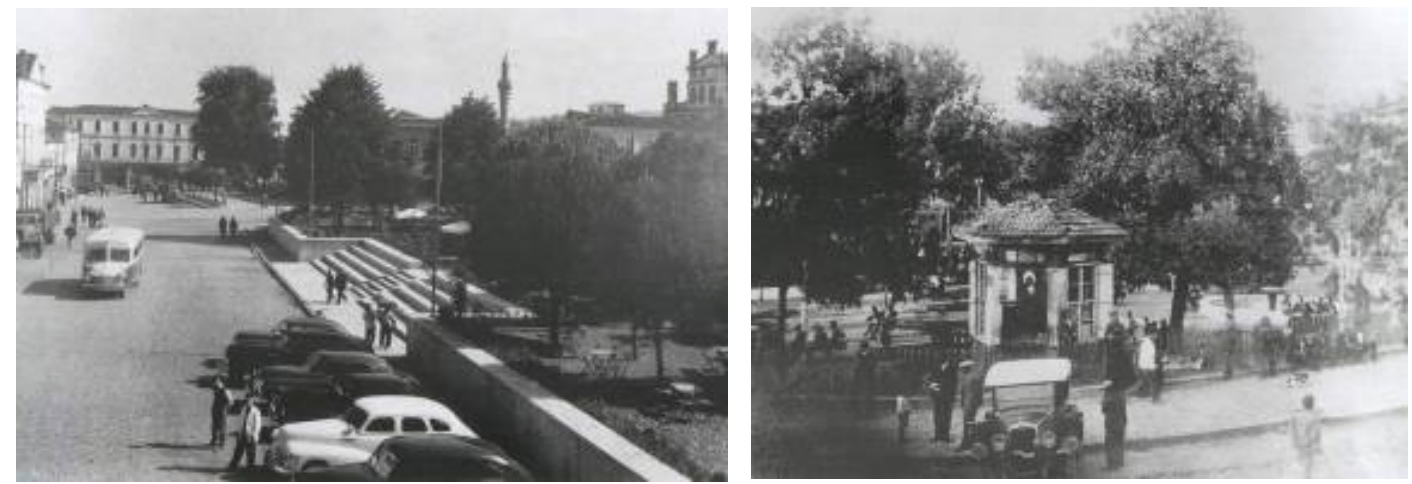

Şekil 6: Meydan Parkının Güneyi 1925 ,Meydan Parkı Kuzeyi, (Url-2, 2019).

Özellikle kent meydanını çevreleyen yapılar, kentin odak noktasında bulunmasından dolayı, kent ve kentli için anlamlı yapılar bütününü oluşturmaktadır. Tarihsel süreçte kent merkezinde değişen, yenilenen ve tarihi dokularını halen koruyan yapılar bir arada bulunmaktadır (Şekil 6).

Kent meydanında ölçeği ve odak noktasında olması ile baskın olarak varlığını hissettiren meydan parkı bulunmaktadır. Meydan parkı kentin merkezinde bulunduğundan kentliler için buluşma yeri olma özelliğini göstermektedir. Meydan parkının çevresini tamamen kaplayan yapılar; kentin merkezinde bulunmalarından dolayı kent kimliğinde önemli bir yer edinmektedir. Kentler belirli merkezlerle 
anılmaktadır. Trabzon kenti içinde en önemli merkez kentin odak noktası ve kentin en önemli göstergesi Kent Meydanıdır.

Atatürk Alanının bu kadar etkin bir öneme sahip olmasında en önemli etkende kentin en eski tarihinden beri varlığını sürdürmeye çalışan yapılarının burada varlığını korumasıdır. Bu yapılar yeni yapılar ile bitişik nizamda sıralanmaktadır. Yeni yapılar eski yapılara göre daha yüksek katıdır ve farklı bir cephe kurguları ile eski yapılardan ayrılmaktadır.
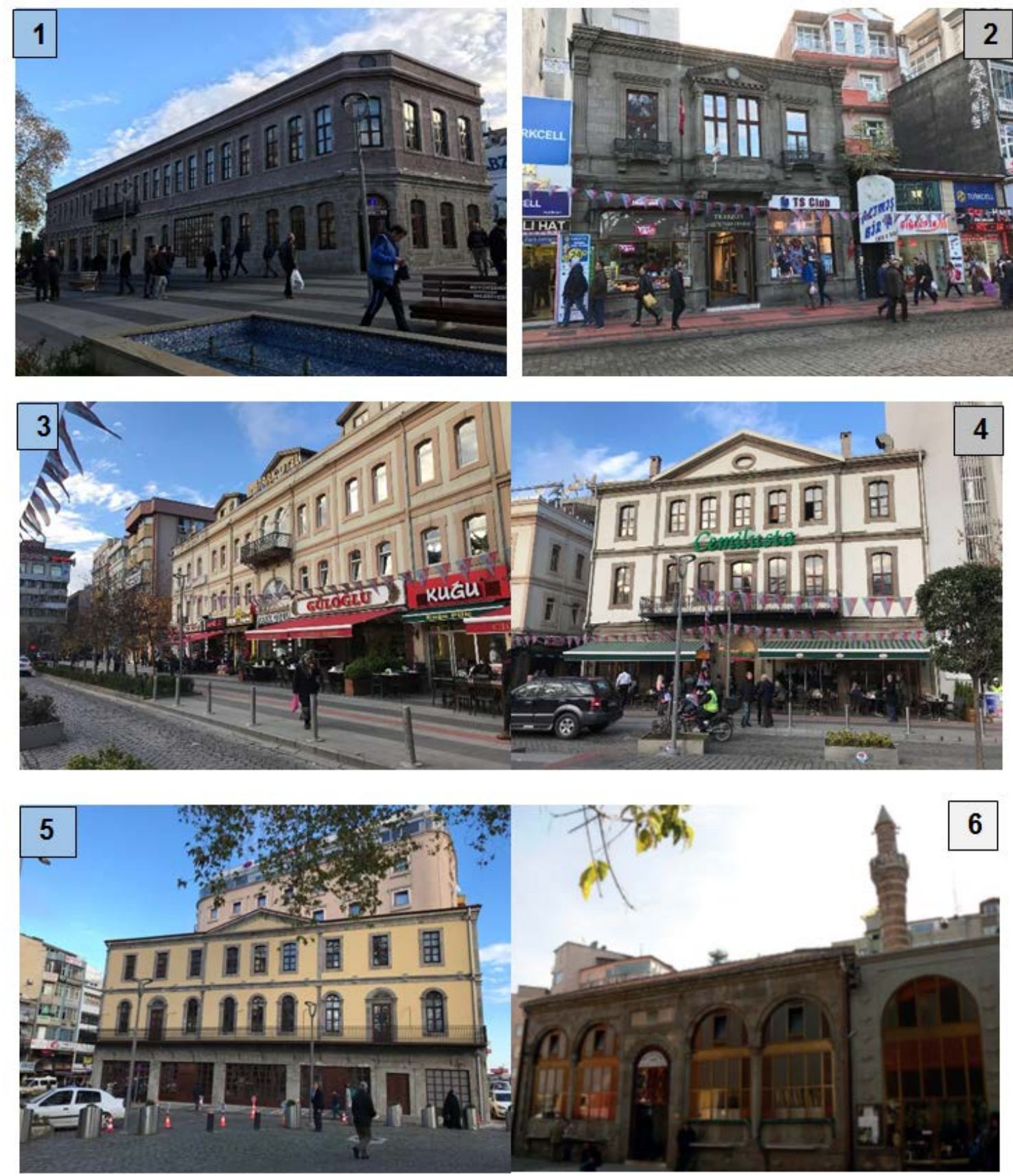

Şekil 7. 1. Belediye Binası 2. Gazeteciler Cemiyeti, 3. TS Park Oteli, 4. Kunduoğlu Konağı(Cemil Usta), 5. Eski Selamet Oteli, 6. İskenderpaşa Camii (Fot. Funda Kurak Açıcı).

Kent meydanında en etkili olan yapılar daha küçük ölçekte olmalarına karşın eski yapılardır. Etkin olmalarındaki en önemli sebepte tarihsel kimlikleri, kente saygılı 
duruşları, kültürel özellikleri olarak değerlendirilmektedir. Meydan Parkı çevresinde 8 eski yapı 14 yeni yapının varlığı tespit edilmiştir. Yeni yapıların eski yapılara oranla çok olması dikkati çekmektedir. Tüm bunlara rağmen eski yapıların kent meydanında daha etkili oldukları ve meydana hakim oldukları görülmektedir. Bu yapılardan en baskın olanları Belediye Binası, Gazeteciler Cemiyeti, Yeşilyurt Oteli ve Kunduoğlu Konağı Eski Selamet Oteli (Günümüzde Kafe) ve İskender Paşa Camii birer kent göstergesi görünümündedir (Şekil 7). Özelikle bu yapıların cephe kurgularında tek renk hakimiyeti ve malzeme olarak sade doğal taş malzemenin kullanılması asil bir görüntü oluşmasına neden olmuştur.
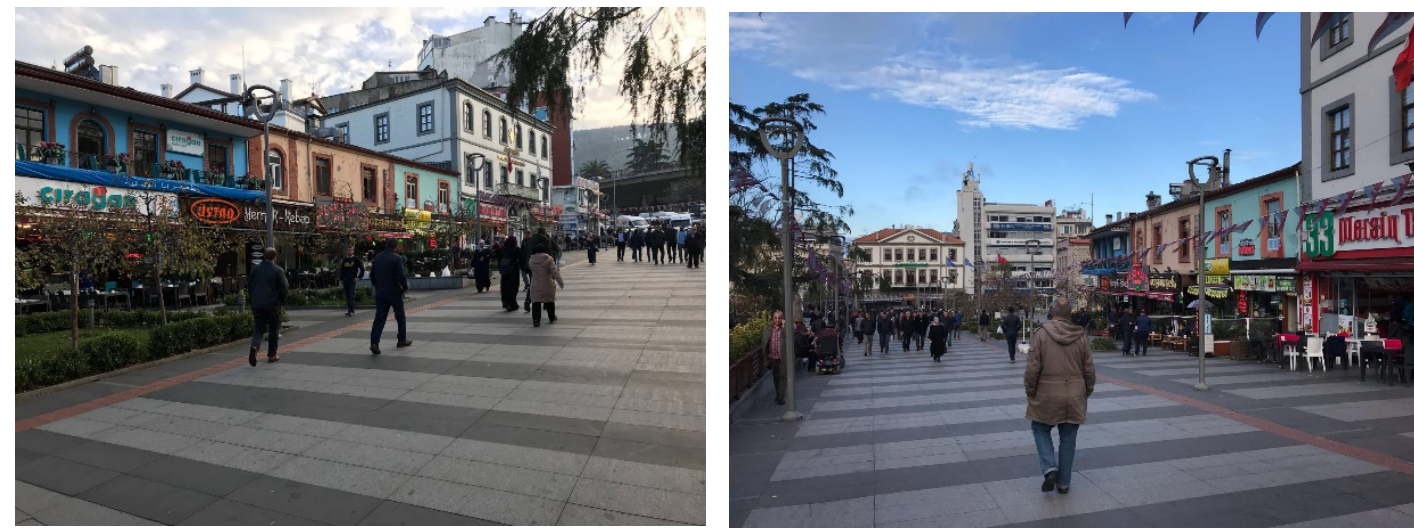

Şekil 8. Meydan Parkı Doğu Tarafındaki Tarihi Yapılar (Fot. Funda Kurak Açıcı).

Özellikle Belediye Binası ve Park Otelinin cephe karakteristiğindeki etkilerinin yanı sıra uzun bir yapı olmalarından ötürü meydana hakim konumları dikkat çekici niteliktedir. Bu iki yapı, kent meydanın adeta birer simgesi olmuş durumda, kenti anlatan en belirgin göstergeler arasındadır. Meydan çevresindeki günümüze ulaşan tüm tarihi yapıların cephe kurguları ve konumları itibari ile özel bir öneme sahiptir. Diğer eski yapıların bu dört yapı kadar etkili olmaması, kentin merkezinde bulunmalarından dolayı ticaret alanı olarak hizmet vermeleri ve bu nedenle de cephelerinde çok fazla tabela bulundurmaları ile açıklanabilmektedir (Şekil 8).

Jakobson'un iletişim modeli çalışmanın konusunu oluşturan Kent Meydanının göstergebilimsel çözümlemesi içinde uygulanabilir ve açıklayıcı görülmektedir. Yapı mimarları da tıpkı bir konuşan özne gibi alıcısına bir ileti aktarmak ister. Jakobson'un iletişim şemasındaki iletinin Kent Meydanındaki tarihi değer taşıyan yapılar için de geçerli olduğu kabul edildiğinde ortaya bir grafik anlatım çıkmaktadır (Şekil 9).

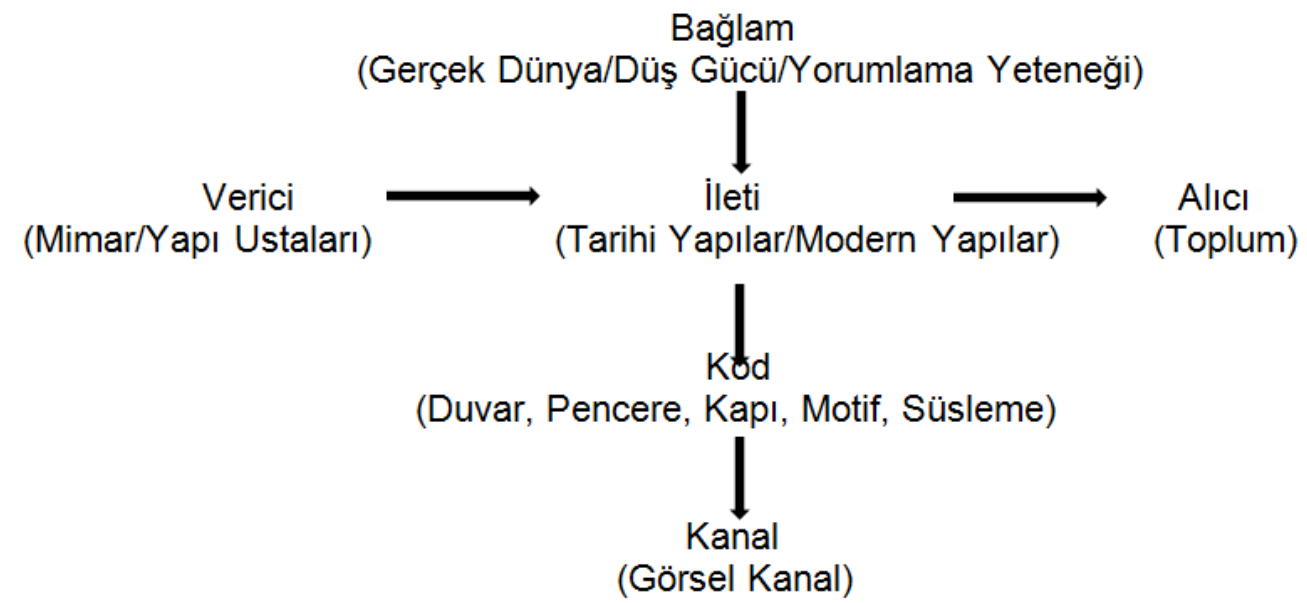

Şekil 9. Kent İçin İletişim Modeli (Güneş, 2013). 
Mimarın iletisi yapılarıdır. İletisini oluşturmak için dış dünyadan yararlanabileceği gibi, kendi düş gücünden ve yorumlama yeteneğinden de yararlanır. İletisini yaparken değişik motifler, teknikler, ve taş kullanır. Eserini ortaya koyarken kullandığı kanal gözdür, yani görsel kanaldır. Toplumun görme, fark etme, anlama ve yorumlama yeteneğine bırakmıştır (Güneş, 2013). Bu çalışmada da, kent merkezini oluşturan kentin ulaşım ağının çevrelediği meydan alanı ve etrafında bulunan yapıların kent halkı üzerinde bıraktığı etki ile kent için bir iletişim biçimi ortaya koyulmaktadır

\section{DEĞERLENDIRME VE SONUÇ}

Kent, birbirinden çok farklı kavramların bir arada olduğu görsel çatışmaların toplamından oluşmaktadır. Bu çatışmaların her birinin farklı okunması kenti kendi içinde yeni anlamlar barındırmaya iter. Bir anlamda kent, okumalar sonucunda özgün söylemler oluşturur ve her söyleme farklı bir anlam yükler. Kenti anlamaya neden olan her bir nesne, kendi başına anlam ifade etmez. Çünkü kent tüm anlamların bütünüdür. Mekanları okumak, onları duyumsamakla ilgilidir. Algının insanın zihninde izler bırakmasıyla kentin bıraktığı imaj, uzun bir süreçte parça parça algılanır. Her parçanın bir araya geliş şekli, o şeylerin göstergesidir. Kent, yapılanmış birçok şey gibi göstergelerle yoğun bir şekilde doludur. Ama bu göstergelerin ifadesi kent için daha karmaşık anlamlarla ifade bulur. Trabzon kent merkezini oluşturan kent meydanındaki anlatımda, kenti oluşturan toplumun ortak yaşam yolu içindeki kesişme alanını gözlemlenebilmektedir. Kendine has bir yerleşim ve peyzaj anlatımı ile kentin bir kimlik kazandığı anlaşılmaktadır. Kent meydanında dizgesel olarak çağrıştırdığı anlamları somutlaştırarak mekan formunun bellekte oluşturduğu anlam ile üstlendiği işlev arasındaki benzeşim ve farklılıklar ortaya koyulmaktadır.

Kentin okunmasını sağlayan, kenti oluşturan tüm göstergelerdir. Kentin merkezinde yer alan kent meydanı, Trabzon kenti için en önemli kent göstergesidir. Kenti okuyabilmek için, anlamlama göstergebilimden yararlanılmış, kentin gözlemlenebilmesini sağlayan somut fiziksel nesneler olan meydan alanı ve meydanı çevreleyen yapılar yorumlanmıştır.

Trabzon kent meydanı, kentin merkezinde odak noktasında, kentin en önemli göstergesi olarak konumlanmıştır. Kenti tanımlayan, kentin geçirdiği tarihi dönemleri, yaşamdan izleri ifade eden, kenti anlatan, kenti anlamlandıran kent meydanın kimliğidir. Kentin kimliğini anlatan meydan, konumu, formu, etrafını çevreleyen yapıları, etrafını çevreleyen yolları ve ulaşım noktasında olması gibi gösterenlerle kurduğu iletişimle kenti anlamlandıran bir göstergedir. 


\section{KAYNAKLAR}

Arü, A.K., Türk Kenti, 1. Basım, İstanbul, 1998, Yem Yayın.

Aras, A., İslamoğlu, Ö. "Palimpsest Bir Kent Trabzon'un Katmanlarının Mimari Eserler Üzerinden Okunması", International Conference on Multidisciplinary Sciences, İstanbul Medipol University, 2018, ss. 917-935.

Çevik Ö., "Tarihte İlk Kentler ve Kentleşme Süreci", 1. Basım, İstanbul, 2005, Arkeoloji ve Sanat Tarihi Yayınları.

Erkman, F., Göstergebilime Giriş, İstanbul, 1987.

Kurak Açıcı, F., Sınır Kavramı ve İç Mekan İlişkisi: Yaşama Mekanları Örneği, Doktora Tezi, Trabzon: KTÜ, Fen Bilimleri Enstitüsü, İç Mimarlık Ana Sanat Dalı, 2013.

Güneş, A., Bir Eserin Mimarisini Göstergebilimsel Bir Yaklaşımla Okuma Ya Da Mimari Göstergebilim: Divriği Ulu Camii Ve Darüşşifası, Erciyes İletişim Dergisi "akademia" Cilt: 3, Say:2, 2013, ss.74-86.

Öksüz M., 1746-1789 Tarihleri Arasında Trabzon'da Sosyal ve Ekonomik Hayat, Doktora Tezi, Ankara: Ankara Üniversitesi, Sosyal Bilimler Enstitüsü, 2004.

Öztaşkın B., "Tarihe Tanıklık Etmiş Meydanlar”, http://www.arkitera.com/h28301-tarihetaniklik-etmis-meydanlar.html. Erişim Tarihi: 12.01.2019.

Rifat, M., Göstergebilimin ABC'si, 3. Basım, İstanbul: Say Yayınları, 2009.

Rossi A., Şehrin Mimarisi, çev. Nurdan Gürbilek, İstanbul: Kanat Yayınları/Deneme Dizisi, 2006.

Ter Ü. ve Özbek O., "Kent Merkezlerinin Oluşumunda Alansal Gömülülük: Konya Tarihi Kent Merkezi”, Ankara: Gazi Üniv. Müh. Mim. Fak. Der. Cilt 20, No.4, 2005, s. 527-536.

Turan Ş., Türkiye-İtalya İlişkileri I: Selçuklular'dan Bizans'ın Sona Erişine, İstanbul: Metis Yayınları, 1990.

Url-1: "Trabzon Kent Meydanı Haritası", https://earth.google.com/web/@ 41.00526397,39.73089215,2.06613155a,406.80571442d,35y,11.53753025h,60.00070 619t,-Or, Erişim Tarihi: 14.12.2017.

Url-2: "Trabzon Kent Meydanı", http://erdemsavaser.blogspot.com/search/label/ trabzon \%20history. https://www.resimars.net/r-turkiye-1526-trabzon-1685-trabzonmeydan-parki-eski-gorunumu-32732.htm, Erişim Tarihi: 10.01.2019.

Yalçınkaya Erol, Ş. ve Demirkaya Ü., F., "Trabzon Kentinin Kalbi: Tarihi İzleri ile Atatürk Alanı", V. Özek, G. Dalgıç ve G. Karakaya (Ed.) 7.Uluslararası Sinan Sempozyumu, 2011, ss. 158-165. 